Meta

Journal des traducteurs

Translators' Journal

\title{
TERUSB III: A System Description
}

\section{Dolores Raventós De Castro}

Volume 36, numéro 1, mars 1991

La terminologie dans le monde : orientations et recherches

URI : https://id.erudit.org/iderudit/003914ar

DOI : https://doi.org/10.7202/003914ar

Aller au sommaire du numéro

Éditeur(s)

Les Presses de l'Université de Montréal

ISSN

0026-0452 (imprimé)

Découvrir la revue

Citer cet article

Raventós De Castro, D. (1991). TERUSB III: A System Description. Meta, 36(1), 201-206. https://doi.org/10.7202/003914ar

\section{Résumé de l'article}

On cite d'abord dans l'ordre chronologique les sept phases du développement du TERUSB III puis, on élabore sur chacun des 4 niveaux d'implantation des systèmes TIS avant d'expliquer la fonction de chaque sous-système du TERUSB III. Ensuite, la version 1.0 du TERUSB III est décrite à l'aide de quelques options disponibles dans le menu principal et certains aspects étudiés pour

l'élaboration de la prochaine version sont exposés. On mentionne enfin des emplois possibles du système et ses applications nationales et internationales.
Ce document est protégé par la loi sur le droit d'auteur. L'utilisation des services d'Érudit (y compris la reproduction) est assujettie à sa politique d'utilisation que vous pouvez consulter en ligne.

https://apropos.erudit.org/fr/usagers/politique-dutilisation/ 


\title{
TERUSB III: A SYSTEM DESCRIPTION
}

\author{
Dolores Raventós De Castro \\ Universidad Simón Bolívar, Caracas, Venezuela
}

RÉSUMÉ

On cite d'abord dans l'ordre chronologique les sept phases du développement du TERUSBIII puis, on élabore sur chacun des 4 niveaux d'implantation des systèmes TIS avant d'expliquer la fonction de chaque sous-système du TERUSBIII. Ensuite, la version 1.0 du TERUSBIII est décrite à l'aide de quelques options disponibles dans le menu principal et certains aspects étudiés pour l'élaboration de la prochaine version sont exposés. On mentionne enfin des emplois possibles du système et ses applications nationales et internationales.

\section{BACKGROUND}

The TERUSB emerges as a progression of the BTUSB (Terminological Data Bank of the Universidad Simón Bolivar), to satisfy the need to create an environment at a microcomputer level for information professionals ${ }^{1}$, so that they may process, analyze and retrieve multilingual terminological data and validate the same ${ }^{2}$.

\section{CHRONOLOGY OF SYSTEMS AND EXPERIENCES}

We could mention seven phases-software experiences in the development of the TERUSBIII:

1. TERUSBI (1976): program written in COBOL for a DECl0 environment; trilingual but in upper case; diacritics had to be incorporated by hand.

2. TERUSB 1.1 (1978-81): bilingual, semi-automatic; first venture into a new more formal record structure following the recommendations of Dubuc ${ }^{3}$ and Rondeau 4 .

3. TERUSB 1.2 (1984): adaptation of the TERUSB I to a new subject field; still confronting the limitation of upper cases and diacritics.

4. SITUSBI (1986): first venture into a microcomputer environment where we tested trilingual processing, without excluding multilingual possibilities, using dBaseIII without programming but with the Applications Generator.

5. SITUSBII (1987-88): multilingual processing in dBaseIII+, with programming, as a basis for the TERUSBII.

6. TERUSBII (1988): multilingual in dBaseIII+ and Foxbase+, with programming, over 90 screens - programs, to navigate through all the activities ${ }^{5}$.

7. TERUSBIII (1989-90): an upgrade of the TERUSBII, multilingual in dBaseIV, which is considered to be essentially our final objective-system.

\section{TERMINOLOGICAL INFORMATION SYSTEMS (TIS'S):} FOUR LEVELS OF IMPLEMENTATION

\section{A. DEFINITION}

We defined a TIS as a "system which consists of a series of elements or subsystems, whose functions are destined to converge or disseminate terminological information processes related to general or specific aspects of a given subject field" 5 . 
These systems can be developed adequately at four implementation levels, depending on the number of users, subject fields covered and the processing equipment available.

1. First level: 1 user, 1 subject field, 1 workstation. Minimum hardware (workstation) configuration: $1 \mathrm{MgB}$ RAM, 1.2 MgB disk drive, $40 \mathrm{MgB}$ Hard Disk. (Note: up to TERUSBII, we were contemplating the minimum hardware configuration at an IBM-XT level: $640 \mathrm{~K}, 20 \mathrm{MgB}$ Hard Disk level, but given the characteristics of the new DBMS - software packages, we had to upgrade this configuration to an AT level, be it a compatible, MCA or EISA configuration.) At this level, data can be processed adequately without programming, by using the Application Generator that comes with the software package, and the resulting data can be integrated manually with some word processors.

2. Second level: 1 or more users, several subject fields, one workstation. Minimum hardware configuration: the same as level one, but contemplating an average of 10-20 MgB per subject field. This level requires a certain amount of programming.

3. Third level: several users, several subject fields, several workstations. Minimum configuration: 4-6 MgB RAM, 286 or 386 processor, multiuser or Local Area Network (LAN), and at present we are studying the possibility of interaction with compact disks beyond the read-only capacity.

4. Fourth level: the same as the third but at a mainframe level. Given the present trend of 386 and 486 super-micros, it becomes feasible to develop at a supermicro level what was required previously to do at a minicomputer or mainframe level.

\section{B. ACCESS AND CONTROL ASPECTS}

The access and control by the user decreases proportionately as the systems grow. The access protocols are imposed by the managers of the systems (starting with the second level), and in the cases of minicomputers, these have to submit to and comply with higher controls.

\section{THIRD WORLD CONTEXT}

For Third world applications, it is believed that the third level would be the most convenient, as it would offer the best of both extremes.

\section{THE TERUSBII AS A TIS OF THE BTUSB (Conceptual Description). (See Annexes 1 and 2)}

\section{A. INSTITUTIONAL CONTEXT}

Within our institutional context, the TERUSBIII turns out to be the TIS that activates the function of the BTUSB. (See Annex 3)

The said system consists of eight subsystems through the incorporation of two additional systems to the TERUSBII ${ }^{6}$.

1. Subsystem 1: SITER (Sistema de Información Terminolgica = Terminological Information System) Constitutes the nucleus of the TERUSBIII as it is the subsystem that processes the terms, while concentrating and codifying the information that is amplified in the other supporting subsystems.

2. Subsystem 2: SIAT (Sistema de Información de Areas Temáticas = Information System for Subject Fields). This system acts as a processing module for the subject field information which shall serve as a basis for the final classification of the 
subject fields to be developed within the same. It reflects four nesting levels. The reason for our selecting such an option is that when we analyzed several classification systems for adaptation and incorporation into the TERUSBIII, such as the Lenoch, Termium, UNESCO, etc., none of them was able to fully satisfy certain of our needs. We thus opted for developing this open four level system. This approach is justified as a converging mechanism for the different prevailing classification systems, paving the way toward a more complete classification, serving as a catalyst for interdisciplinary aspects in the search for and making of decisions related to classifications. At this stage we shall be able to contemplate the dynamics of certain new sciences, such as bioelectronics or geophysics, and record their terminological evolution.

3. Subsystem 3: SIDOC (Sistema de Información Documental $=$ Documentary Information System). This system covers three types of reference sources: documents, bibliographies and standards. In a context-infrastructure of advanced automation, it could be merged with a Micro-Marc or Micro-Isis, but bearing in mind that in some third world situations one would not necessarily have access to any such options, this subsystem could be used to solve the most essential and relevant process.

4. Subsystem 4: SIUGE (Sistema de Información de Uso Geográfico = Information System for Geographic Use). This system would contain and process information pertaining to linguistic variations within each language family.

5. Subsystem 5: SIET (Sistema de Información de Especialistas TemáticosTerminológicos = Information System for Subject Specialists and Terminologists). This system stores and processes information to give access to the specialists when needed for consultation and publication purposes.

6. Subsystem 6: SIBEM (Sistema de Información de Bancos Emisores = Information System on Emitting Data Banks). This system accesses the code and amplifies the data of the EDB, such as the necessary information for data exchange.

7. Subsystem 7: SILEN (Sistema de Información de Lenguas = Information System on Languages). This system stores and processes the information of the different languages present in the system and facilitates the incorporation of new languages so that the screen commands could appear in the said languages when needed.

8. Subsystem 8: SIEST (Sistema de Información Estadística = Statistical Information System). This system generates control statistics about the system, such as: the number of terms, frequency of consultation and use.

\section{TERUSBII, VERSION 1.0; DESCRIPTION THROUGH SOME SCREENS}

\section{A. GENERAL COMMENTS}

The basic philosophy of the TERUSB is its userfriendliness and ease of use so as to reduce to a minimum any necessary training. The user navigates through the system with the cursor, and receives auditory signals of important steps or messages. He is always informed on the screen about the process, action or menu where he is located. As of the first session, he determines his source language and can handle several target languages. Should his language not be present in the system, it can be incorporated into it so that the screen commands can appear in the said chosen language.

(NOTE: The system has over 90 screens, depending on the combinations of options requested; we shall focus on a few of them to give some idea of the system) 
The Main Menu comprises three types of major actions:

1. Options: these are the main usage alternatives, such as the choice of source and target languages, the selection of subject field, the transfer of data to other programs and the determination of usage level (system manager or general user). Should the person choose the user level, he will have the capacity to consult the data, but will not be able to modify them. Being the system manager, the terminologist has full access to any part of the system and complete control of the same after password clearance.

2. Maintenance: In this section, we have the backup, restore and file reconstruction options.

3. Exit: This Section contains the corresponding option to leave the TERUSB System either temporarily into the OS or permanently.

4. Screens: Two examples.

a. Annex 4 is an example of the tree of options which the user can use to navigate through the system.

b. Annex 5 is an example of a document information.

\section{SOME ASPECTS CONTEMPLATED FOR OUR NEXT VERSION}

Until now, given our hardware limitations, we have always catered to the personal microcomputer. That is not to exclude the possibility of amplifying the system for a LAN application.

Another aspect that will be considered in the next couple of years is the interaction with Compact Discs, beyond the ROM capacity.

A third aspect would be the graphic presentation of terms in tree structures.

\section{APPLICATIONS OF THIS SYSTEM}

Even though in this publication we are contemplating the system from a terminological point of view, we should not forget that, given our institutional characteristics, our system and applications can be expanded to include other activities involving different kinds of information professionals. That is why this system is intended:

1. to facilitate the work of information professionals;

2. to simplify the classification processes of subject fields;

3. to reinforce the development of documentary and controlled languages;

4. to eventually facilitate the development of multilingual spell-checkers for word processors;

5. to facilitate the determination of key descriptors in the search of on-line data bases;

6. to consolidate the basis of an institutional thesaurus; and

7. to create an information service environment.

\section{A WISH LIST FOR "AN IDEAL SYSTEM" AND HOW WE RATE}

Vasconcellos and Melby 6 established that an ideal system should: assure compatibility; offer a flexible record layout; easily handle diacritics; facilitate on-line search; offer utilities for file handling; incorporate options for data exchange through predetermined formats; have a capacity to function as a network; have a sufficiently rapid answer mode; be able to interact with word processors; offer simple menus for beginners 
in the field; have the backing of terminologists; and finally should be of a reasonable price.

The BTUSB and TERUSB are at present at a $65 \%$ level of compliance with the above and we are working toward $100 \%$.

\section{INSTITUTIONAL PROJECTIONS}

A. A system such as this one could have national and international projections.

[See Annex 3]. We shall mention three national and two international projections.

1. Universidad Simón Bolívar (USB)

The BTUSB and the TERUSB are going to actively back the activities of the new academic library in its automation and incorporation of new information transfer techniques. It is also serving as a Laboratory for the Graduate Program of Information Studies.

\section{Universidad de Los Andes (ULA)}

A TDB and system such as ours could serve as a basis of agreement with other national institutions such as the ULA, where a TDB is being developed. We could share terminologies common to both institutions and use the same processing system.

\section{USB + CONICIT + COVENIN}

On a national level, a TDB and system such as this one could serve as an element of convergence for the automation of terminologies of interest to universities, to the Ministry for Science and Technology (CONICIT) and the National Standards Institute (COVENIN).

\section{Canada and Sweden}

Given the fact that the essence of our record is based on the Termium structure and that we have some twenty subject fields in common with the Canadian Government Terminology Bank, it should not be difficult in some near-mid-term basis to interact with their $\mathrm{CD}$ format. We would have to wait for the $\mathrm{CD}$ juke-box contemplated for our library and study the feasibility of completing their data in Spanish in our common fields.

In the same manner, the vocabularies we processed-completed for the TNC-Sweden glossaries, because of hardware limitations remained on cards which could be incorporated to the CD of the TNC.

At present, both are on a CD-ROM basis. We would work toward a possibility of writing in those CDs.

\section{GLOBAL PERCEPTION OF OTHER SYSTEMS}

One of the aspects of our reaching a certain maturity was when we decided to stop keeping up with any of the big systems such as those of the Canadian Government, Quebec, Eurodicautom, etc. We reached a point where it was either subjugating and sacrificing our needs and record structure to duplicate theirs, or catering to our needs and establishing a record structure to satisfy our requirements. We opted for the latter. Nevertheless, we must state that given the present trends of conversions between different systems and programs, we envisage that the data exchange should not be as uphill as it was in the past. Ever since the minimum terminological data elements were agreed upon in 1981, we intend to at least exchange at that level, all other data being considered strictly for our local application and perhaps of little use to other setups. Data exchange for the time being and near future will have to be limited to bilateral agreements. 


\section{CONCLUSIONS AND FUTURE TRENDS FOR THE TERUSB}

A. The main conclusion that we can derive is that we have come a long way in the past ten years and have reached quite valid solutions for our environment and needs. We have made the most of our small size without hindering or closing our communication options with bigger systems.

\section{B. Short-, Mid- and Long-term Perspectives}

For the short-term, we shall be giving the final touches to the system and manuals in the next month and registering it for future marketing.

For the mid-term, we shall be setting it up on a more powerful micro, with the incorporation of additional resident subject fields.

For the long-term, we should be able to interact with and write on Compact Disks, which given our magnitude, would overcome all problems of size and limitations.

\section{NOTES}

I. Raventós de Castro (1988)

2. Raventós de Castro (1989)

3. Dubuc (1978)

4. Rondeau (1981)

5. Op. cit. see 1 .

6. Vasconcellos (1988)

- Project Research Assistants and Programmers:

* Carlos Maldonado Montagne, SITUSBII and TERUSBII programmer;

* Ana Luisa Rodriguez Coricote, Administration and Teaching Aids;

* Iván Centeno Román, TERUSBIII programmer and software evaluation:

* Alberto Benzaquén Wahnich, TERUSBIII programming assistant;

* Antonio Márquez Mata, TERUSBIII programming assistant and tutorials.

\section{BIBLIOGRAPHY}

DUBUC, Robert (1978): Manuel pratique de terminologie, Montréal, Linguatech.

RAVENTOS DE CASTRO, Dolores (1988): Sistemas de Información Terminológica (SITs): Cuatro Niveles de Solución y Aplicación, Caracas, I Simposio Latinoamericano de Terminología.

RAVENTOS DE CASTRO, Dolores (1989): Desarrollo e Implantación de una Opción de Bancos de Datos Terminológicos Multilingüe A Nivel de Microcomputadora para Aplicaciones en el Tercer Mundo, Caracas, Universidad Simón Bolivar.

RONDEAU, Guy (1981): Introduction à la terminologie, Québec, Centre Éducatif et Culturel, Inc.

VASCONCELLOS, Muriel (Editor)(1988): Technology as Translation Strategy, New York, American Translators Association - Scholarly Monograph Series, 2, State University of New York. 